\title{
Pengaruh kedalaman las pada pengelasan gesek puntir dua muka logam Magnesium AZ31
}

\author{
Irza Sukmana ${ }^{1)^{\star}}$, Hafiz Favian Gustin ${ }^{1)}$, Tarkono ${ }^{1)}$ \\ 1) Jurusan Teknik Mesin, Fakultas Teknik, Universitas Lampung \\ Jalan Prof. Soemantri Brojonegoro No. 1, Bandar Lampung 35143 \\ *Email korespondensi: irza.sukmana@gmail.com \\ Naskah diterima 05/01/2021; direvisi 24/03/2021; disetujui 30/04/2021 \\ doi: https://doi.org/10.24843/JEM.2021.v14.i01.p02
}

\begin{abstract}
Abstrak
Pengelasan merupakan salah suatu proses produksi yang bertujuan untuk menyambungkan dua atau lebih bahan teknik. Teknolgi Las Gesek (Friction Welding, FW) merupakan salah satu teknik pengelasan padat yang tidak memerlukan logam pengisi. Pembangkitan panas yang dalam proses FW dihasilkan dengan cara menggesekkan dua permukaan material las (base metal) hingga mencapai temperatur setengah padat (semi-solid) atau sekitar $80 \%$ temperature cair bahan. Setelah bahan mencapai temperatur semi-solid tersebut, kemudian diberi tekanan pada spindle agar kedua material tersambung. Penelitian ini bertujuan untuk mengetahui kekuatan tarik, struktur makro, dan nilai kekerasan magnesium yang telah dilakukan pengelasan. Penelitian ini dilakukan dengan beberapa variasi pengujian waktu kontak pengelasan, yaitu pengujian dengan waktu kontak selama 3, 5, dan 10 menit. Sedangkan kecepatan putar spindle berberak yang digunakan adalah sebesar 1400 rpm. Pengelasan dengan waktu kontak gesek 3 menit, menghasilkan kekuatan tarik tertinggi dibandingkan dua parameter lain, yaitu sebesar 16,78 Mpa, dan pengelasan dengan waktu kontak gesek 10 menit mempunyai nilai uji kekuatan tarik terkecil yaitu 4,25 MPa. Selanjutnya, uji keras pada daerah las (stir zone) menunjukkan angka kekerasan rata-rata yang konsisten, yaitu sebesar $60 \mathrm{HR}_{\mathrm{E}}$, sedangkan angka kekerasan rata-rata di daerah terpengaruh panas (heat affected zone, HAZ) untuk waktu kontak gesek 3, 5 dan 10 menit secara berturut-turut adalah sebesar 69,6, 64,6 dan 60,6 HR. Hasil penelitian awal ini memberikan potensi studi lanjutan pada berbagai parameter pengelasan lain agar didapatkan kualitas sambungan las gesek yang optimum untuk proses pengelasan gesek Magnesium AZ-31.
\end{abstract}

Kata kunci: Friction stir welding (FSW), kedalaman las, pengelasan dua sisi, Magnesium AZ31

\section{Abstract}

Friction Stir Welding (FSW) categorized as solid-state welding method. The working principle of FSW is to utilize combination of rotation of tool and penetration force to produce heat energy which changes the workpiece phase to be semi-solid and make in possible to joined. Magnesium is a light metal that is widely used in aircraft, automotive, construction, and medical equipment components. In this study, AZ31 magnesium metal welding was joined by friction stir welding method which was applied to the upper and lower surfaces of the workpiece or called double side friction stir welding (DFSW). DFSW method aims to obtain joining without having to change the workpiece phase into a liquid, this is because magnesium is a metal with a low flame temperature characteristic. With the DFSW method, the potential for the workpiece to burn during the joining process can minimized better than joining by conventional welding methods that is fusion welding method. There are 3 variations of the depth of weld parameters that are applied in this study $1.6 \mathrm{~mm}, 3.6 \mathrm{~mm}$, and $5.6 \mathrm{~mm}$. From this research, it is known that the depth of weld factor greatly affects the quality of the resulting joints, based on testing it is known that the best results are obtained with a depth of weld of $5.6 \mathrm{~mm}$.

Keywords: Friction stir welding (FSW), depth of weld, two side welding, Magnesium AZ31

\section{Pendahuluan}

Las gesek puntir atau biasa disebut friction stir welding (FSW) adalah metode las yang dilakukan dengan mengkombinasikan panas dan tekanan untuk merubah fasa logam sehingga memungkinkan untuk dilakukan penyambungan. Pada proses FSW panas yang diperoleh dari gesekan benda kerja akan merubah fasa pada area sambungan menjadi semisolid sehingga peroses dapat dilakukan. FSW merupakan metode penyambungan yang cocok untuk diterapkan pada logam dengan titik leleh rendah seperti Aluminum ( $\mathrm{Al}$ ) dan Magnesium (Mg) karena termasuk dalam kategori solid state welding atau penyambungan yang dilakukan dalam keadaan solid (Marinov, 2010).

Magnesium merupakan logam ringan dengan berat jenis $1,74 \mathrm{~g} / \mathrm{cm} 3$, dikarenakan sifat mekanik yang dimilikinya magnesium banyak dimanfaatkan untuk pembuatan komponen pesawat, otomotif, konstruksi, dan untuk keperluan medis seperti keperluan medis seperti pembuatan implan tulang. Salah satu kelemahan logam dalam hal pengolahan adalah pada sifat mampu panasnya dimana magnesium memiliki temperatur cair $650{ }^{\circ} \mathrm{C}$ dan temperatur nyala berkisar $450{ }^{\circ} \mathrm{C}$ sehingga harus mempertimbangkan metode yang tepat dalam proses pengolahan dan manufakturing (Buldum et al., 2011). 
Double side friction stir welding (DFSW) merupakan salah satu metode las yang cocok untuk diterapkan pada penyambungan logam magnesium, hal ini dikarenakan dengan metode ini hanya diperlukan sekitar $60 \%$ dari temperatur cair benda kerja untuk melakukan penyambungan. Adapun prinsip kerja DFSW adalah dengan memanfaatkan metode FSW pada permukaan atas dan bawah benda kerja. Sebelumnya (Prasetyana, 2016) dan (Ibrahim, 2018) telah melakukan penelitian mengenai Friction stir welding, dimana (Prasetyana, 2016) meneliti pengaruh kedalaman las (depth of weld) pada DFSW alumunium seri 5083, dan (Ibrahim, 2018) melakukan penelitian mengenai pengaruh bentuk pin indentor pada FSW Magnesium AZ31. Kedua penelitian tersebut melatarbelakangi dilakukannya penelitian ini, dimana penelitian ini bertujuan untuk mengetahui pengaruh kedalaman las terhadap hasil DFSW Magnesium AZ31.

\section{Metode Penelitian}

Proses pengelasan dilakukan dengan menggunakan mesin milling tipe VHF3 dengan kecepatan putaran tool $2000 \mathrm{rpm}$ dan kecepatan laju pengelasan $16 \mathrm{~mm} / \mathrm{menit}$. Benda kerja las yang digunakan merupakan dua buah plat magnesium AZ31 (simillar metal) dan tools berupa indentor yang terbuat dari baja SKD 11 dengan pin berbentuk spiral. Adapun parameter kedalaman las yang diaplikasikan adalah 1,6 mm, 3,6 mm, dan 5,6 mm.

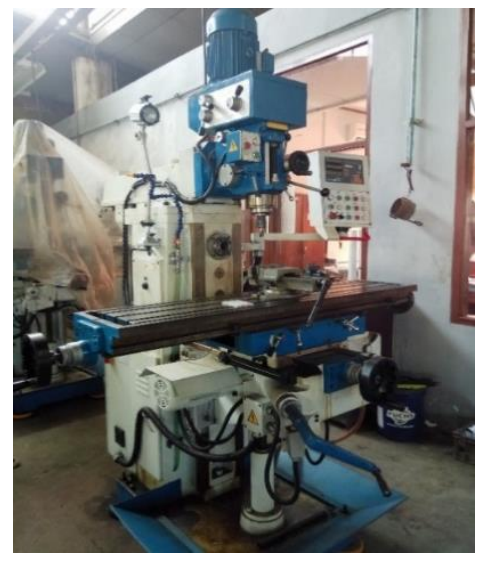

Gambar 1. Mesin milling VHF3

Tabel 1. Spesfikasi Mesin milling

\begin{tabular}{cc}
\hline Nama & Spesifikasi \\
\hline Nomor Mesin & VHF 3 \\
Nomor Seri & 180 \\
Tahun Pembuatan & 2015 \\
Daya & $7 \mathrm{KW}$ \\
Voltase & $380 \mathrm{Volt}$ \\
Frekuensi & $50 \mathrm{GHz} / 3$ Phase \\
Ratasi Min/Maks & $90 / 2000 \mathrm{Rpm}$ \\
Kecepatan & \\
GerakTransversal & $16 / 320 \mathrm{~mm} /$ menit \\
Min/Maks & \\
\hline
\end{tabular}

Pada penelitian ini logam las yang digunakan adalah magnesium AZ31 hasil pengecoran (casting) dengan dimensi panjang $65 \mathrm{~mm}$, lebar $50 \mathrm{~mm}$, dan tebal $6 \mathrm{~mm}$.

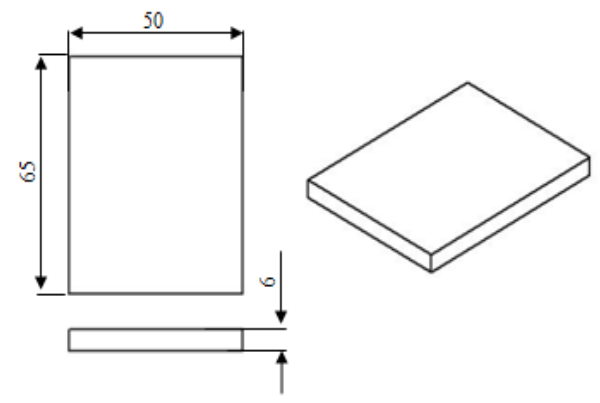

Gambar 2. Dimensi palt Mg AZ31

Untuk mengoptimalkan hasil pengelasan yang dilakukan diperlukan indentor dengan material yang memiliki titik cair dan ketahanan aus lebih tinggi dibandingkan dengan logam las oleh karena itu pada penelitian ini digunakan indentor yang terbuat dari logam SKD 11. Logam SKD11 sendiri merupakan logam baja paduan dengan kandungan karbon sedang yakni berkisar $1.4 \%-1.6 \%$, Chrome $11 \%$ $13 \%$, dan Mo 0,8\%-1,2\%. Selain itu logam SKD 11 memiliki struktur mikro ferrit karbida sehingga logam ini dipilih untuk menjadi bahan pembuatan tools (Santoso, 2014).



Gambar 3. Indentor

Proses pengelasan double side friction stir welding (DFSW) merupakan pengelasan yang memanfaatkan metode yang sama seperti pada metode las friction stir welding (FSW) pada umumnya akan tetapi proses pengerjaan dilakukan pada permukaan atas dan permukaan bawah benda kerja. Berikut ini merupakan tahapan pengerjaan pengelasan metode DFSW.

1. Tahapan pengerjaan DFSW diawali dengan melakukan setting pada mesin milling sesuai parameter yang digunakan serta pemasangan indentor dan logam las.

2. Indentasi awal dengan tujuan memberikan preheating pada logam las.

3. Proses pengelasan, dimana indentor mulai melakukan pergerakan sepanjang welding line dan panas yang dihasilkan sudah mencapai 0.6 Tc (titik cair) dari base metal.

4. Proses pull off atau pengankatan indentor pada ujung welding line.

5. Proses pendinginan logam las hingga terbentuk sambungan sempurna.

6. Mengulangi tahap $2-5$ pada permukaan bawah logam las. 
Untuk mengetahui kualitas sambungan yang diperoleh maka dilakukan beberapa pengujian yakni pengujian kekerasan brinell dan pengujian tarik. Pengujian kekerasan yang dilakukan adalah pengujian kekerasan Brinell, dimana dilakukan indentasi pada base metal (BM) dan pada welding zone yang meliputi heat affected zone (HAZ), thermomechanically affected zone (TMAZ), dan pada stir zone (SZ) pada permukaan atas dan permukaan bawah spesimen. Untuk pengujian tarik diberlakukan pengujian sesuai dengan standar uji tarik ASTM E8/E8M.

\section{Hasil dan Pembahasan}

Gambar-gambar di bawah ini merupakan tampilan visual pada permukaan atas, permukaan bawah dan penampang melintang hasil pengelasan DFSW Magnesium AZ31.

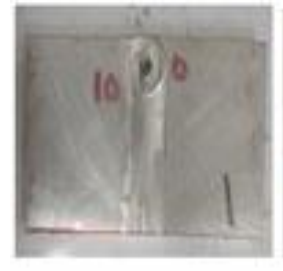

A



B

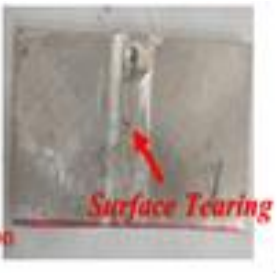

C
Gambar 4. Hasil penyambungan DFSW kedalaman las $1,6 \mathrm{~mm}$. a. permukaan atas, b. penampang melintang, c. permukaan bawah Indentor

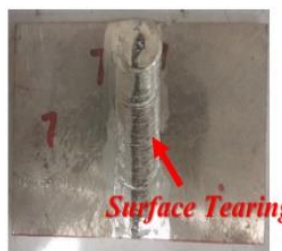

A



B



C
Gambar 5. Hasil penyambungan DFSW kedalaman las $3,6 \mathrm{~mm}$. a. permukaan atas, $b$. penampang melintang, c. permukaan bawah



A

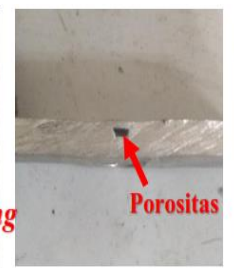

B



C
Gambar 6. Hasil penyambungan DFSW kedalaman

las $5,6 \mathrm{~mm}$. a. permukaan atas, b. penampang melintang, c. permukaan bawah

Cacat las yang dapat teridentifikasi dari pengamatan visual yang dilakukan antara lain cacat worm hole, porositas (running pore), permukaan pecah (surface tearing), dan lack of penetration. Beberapa cacat las tersebut merupakan fenomena yang sering terjadi seperti pada penelitian (Sukmana dan Sustiono,2016) dan (Ibrahim, 2018) juga ada cacat serupa pada hasil FSW yang dilakukan. Ditinjau dari segi kuantitas cacat yang terjadi, dapat terlihat bahwa faktor kedalaman las memiliki andil yang cukup besar dalam menentukan hasil sambungan yang diperoleh.
Pada proses DFSW dengan kedalaman las 1,6 $\mathrm{mm}$ potensi terjadinya lack of penetration bisa dikatakan cukup besar hal ini dikarenakan penetrasi yang dilakukan hanya $53 \%$ dari ketebalan benda kerja, dimana pada penelitian ini digunakan benda kerja dengan ketebalan $6 \mathrm{~mm}$. Cacat porositas yang terjadi pada hasil DFSW dengan kedalaman las 3,6 $\mathrm{mm}$ dan 5,6 mm memiliki ukuran yang tidak jauh berbeda, akan tetapi dari pengamatan yang dilakukan cacat porositas yang terjadi pada spesimen DFSW kedalaman 3,6 mm membentuk suatu pola yang dapat menjadi titik konsentrasi tegangan apabila diberikan pembebanan. Dari penelitian yang dilakukan oleh (Sudrajat, 2012) diketahui bahwa konsentrasi tegangan yang terjadi pada hasil las FSW dapat mempengaruhi nilai kekuatan tariknya, dimana akan terjadi penurunan nilai kekuatan tarik yang cukup signifikan.

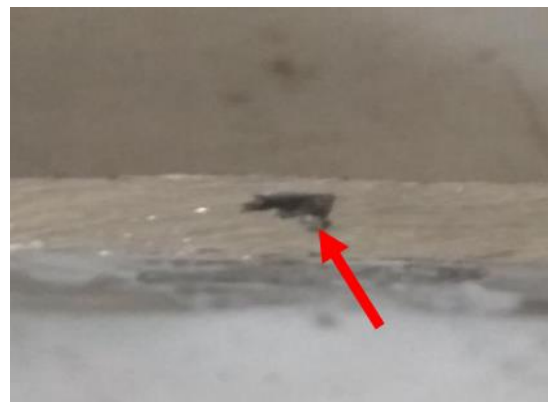

Gambar 7. Titik konsentrasi tegangan

Tabel 2. Cacat las hasil sambungan

\begin{tabular}{cccc}
\hline $\begin{array}{c}\text { Kedalaman } \\
\text { Penetrasi las }\end{array}$ & \multicolumn{3}{c}{ Jenis cacat } \\
\cline { 2 - 4 }$(\mathrm{mm})$ & $\begin{array}{c}\text { Kurang } \\
\text { Penetrasi }\end{array}$ & $\begin{array}{c}\text { Permukaa } \\
\text { Pecah }\end{array}$ & Porositas \\
\hline 1,6 & $\sqrt{ } \sqrt{ }$ & $\sqrt{ }$ & $\sqrt{ }$ \\
3,6 & - & $\sqrt{ }$ & $\sqrt{ } \sqrt{ }$ \\
5,6 & - & $\sqrt{ }$ & $\sqrt{ } \sqrt{ }$ \\
\hline
\end{tabular}

\subsection{Analisa Hasil Pengujian Tarik}

Pada dasarnya pengujian tarik merupakan pengujian yang dilakukan untuk mengetahui sifat mekanik suatu bahan dengan cara memberikan pembebanan tarik yang berlangsung secara kontinyu hingga terjadinya putus (fracture). Pada pengujian tarik spesimen perlu dikondisikan agar memiliki dimensi yang sesuai dengan standar pengujian tarik yang digunakan. Tabel 3 dibawah merupakan data yang diperoleh dari pengujian tarik yang dilakukan.

Dari tabel hasil uji tarik diatas dapat diketahui bahwa hasil sambungan dengan sifat mekanik terbaik diperoleh dari penyambungan dengan kedalaman las $5.6 \mathrm{~mm}$ dimana diperoleh nilai kekuatan tarik maksimum (UTS) sebesar 64.006 $\mathrm{MPa}, 31.928 \mathrm{MPa}$, dan $63.153 \mathrm{MPa}$. Nilai kekuatan tarik maksimum (UTS) merupakan nilai yang merefleksikan kemampuan maksimum suatu material untuk menerima pembebanan tarik, dengan demikian semakin tinggi nilai UTS yang diperoleh maka semakin baik kualitas sambungan yang didapatkan. 
Tabel 3. Hasil pengujian Tarik

\begin{tabular}{|c|c|c|c|c|c|c|}
\hline Spesimen & $\begin{array}{l}\text { Depth Of Weld } \\
\qquad(\mathrm{mm})\end{array}$ & $\mathrm{N}(\mathrm{rpm})$ & $\begin{array}{c}\mathrm{V} \\
(\mathrm{mm} / \mathrm{mnt})\end{array}$ & $\begin{array}{l}\text { Ultimate } \\
\text { tensile } \\
\text { strength } \\
(\mathrm{MPa})\end{array}$ & $\begin{array}{c}\text { Yield } \\
\text { strength } \\
\text { (MPa) }\end{array}$ & $\begin{array}{c}\text { Daerah } \\
\text { Patah }\end{array}$ \\
\hline 1 & \multirow{3}{*}{1,6} & \multirow{3}{*}{2000} & \multirow{3}{*}{16} & 15,204 & 9.126 & SZ \\
\hline 2 & & & & 14,645 & 11,449 & SZ \\
\hline \multirow[t]{2}{*}{3} & & & & 10,569 & 9,825 & SZ \\
\hline & \multicolumn{2}{|c|}{ Nilai rata-rata } & & 13,472 & 10,133 & \\
\hline 4 & \multirow{3}{*}{3.6} & \multirow{3}{*}{2000} & \multirow{3}{*}{16} & 28,503 & 19,088 & SZ \\
\hline 5 & & & & 19,513 & 14,591 & SZ \\
\hline \multirow[t]{2}{*}{6} & & & & 25,584 & 14,872 & SZ \\
\hline & \multicolumn{2}{|c|}{ Nilai rata-rata } & & 24,533 & 16,183 & \\
\hline 4 & \multirow{3}{*}{5.6} & \multirow{3}{*}{2000} & \multirow{3}{*}{16} & 31,928 & 13,401 & SZ \\
\hline 5 & & & & 64,006 & 24,219 & SZ \\
\hline 6 & & & & 63,153 & 27,782 & SZ \\
\hline \multicolumn{4}{|c|}{ Nilai rata-rata } & 53,029 & 21,803 & \\
\hline
\end{tabular}

Dari tabel hasil uji tarik diatas dapat diketahui bahwa hasil sambungan dengan sifat mekanik terbaik diperoleh dari penyambungan dengan kedalaman las $5.6 \mathrm{~mm}$ dimana diperoleh nilai kekuatan tarik maksimum (UTS) sebesar 64.006 $\mathrm{MPa}, 31.928 \mathrm{MPa}$, dan $63.153 \mathrm{MPa}$. Nilai kekuatan tarik maksimum (UTS) merupakan nilai yang merefleksikan kemampuan maksimum suatu material untuk menerima pembebanan tarik, dengan demikian semakin tinggi nilai UTS yang diperoleh maka semakin baik kualitas sambungan yang didapatkan.

Nilai yield strength yang diperoleh berbanding lurus dengan nilai UTS dimana spesimen dengan kedalaman las 5,6 mm memperoleh hasil yang paling baik dan spesimen dengan kedalaman las 1,6 mm memperoleh hasil yang paling rendah.

Perbedaan kualitas sambungan dipengaruhi oleh luasan area adukan pada saat proses penyambungan dengan metode FSW, dimana semakin luas area adukan menyebabkan paduan yang terbentuk menjadi lebih solid dan padat sehingga diperoleh nilai Ultimate tensile strength dan yield strength yang tinggi. Hal ini terbukti dari pengujian yang telah dilakukan dimana semakin dalam penetrasi yang dilakukan maka didapatkan nilai uji tarik yang semakin baik.

Hasil yang diperoleh memiliki korelasi dengan hasil penelitian sebelumnya oleh (Ibrahim, 2018) dimana luasan adukan pada FSW akan mempengaruhi karakteristik sambungan yang terbentuk. kurangnya penetrasi menyebabkan paduan yang terbentuk tidak maksimal dan sangat mudah mengalami crack ditambah dengan terjadinya porositas pada area sekitar permukaan las dan terbentuknya titik konsentrasi tegangan.

\subsection{Analisa Pengujian Kekerasan Brinell}

Grafik dibawah ini menunjukan nilai kekerasan yang telah diperoleh dari uji kekerasan Brinel yang dilakukan pada permukaan atas dan permukaan bawah logam las, sebagaimana pada Gambar 8 dan Gambar 9 berikut ini.

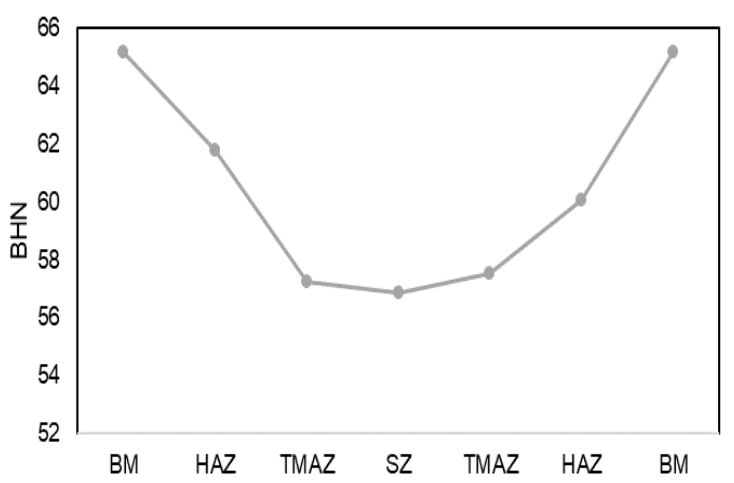

Gambar 8. Grafik uji kekerasan permukaan atas



Gambar 9. Grafik uji kekerasan permukaan bawah

Dari grafik diatas diketahui terjadinya penurunan nilai kekerasan pada welding zone dimana area stirring zone memperoleh hasil uji kekerasan dengan nilai yang paling rendah. Umumnya dari hasil proses pengelasan yang dilakukan area welding zone akan memiliki nilai kekerasan yang lebih baik dibandingkan pada area sekitarnya, akan tetapi pada metode DFSW logam las tidak mengalami perubahan fasa menjadi cair sehingga potensi sambungan tidak terbentuk dengan sempurna cukup tinggi.

Seperti hasil yang diperoleh oleh (Prasetyana, 2016) dimana kualitas sambungan pada area stir zone akan cendrung lebih tinggi dibandingkan pada area HAZ. Terbentuknya cacat las yang merupakan faktor utama terjadinya penurunan kualitas sambungan yang diperoleh (Santos et al, 2007). Hasil pengujian kekerasan menunjukan hasil yang 
cenderung lebih seragam dibandingkan dengan hasil pengujian tarik, hal ini dikarenakan pada saat indentasi dilakukan beban yang diberikan dapat terdistribusi dengan lebih baik.

\section{Kesimpulan}

Kedalaman las (depth of weld) dapat mempengaruhi karakteristik hasil sambungan yang diperoleh. Semakin dalam penetrasi yang dilakukan didapatkan nilai UTS dan yield strength yang cukup baik Kurangnya indentasi pada saat pengelasan dapat memicu munculnya cacat las yakni lack of penetration dan hasil adukan yang tidak sempurna sehingga diperoleh sambungan dengan kualitas kurang baik. Nilai ultimate tensile strength (UTS) dan yield strength (YS) tertinggi diperoleh dengan kedalaman las 5,6 mm yakni 64,006 MPa dan 24,219 $\mathrm{MPa}$, sedangkan hasil terendah diperoleh dari pengaplikasian kedalaman las 1,6 mm yakni 10,569 MPa (UTS) dan 9,825 MPa (YS). Adanya penurunan nilai kekerasan antara area yang terdampak dari proses pengelasan yakni daerah heat affected zone (HAZ), thermomechanically affected zone (TMAZ), dan stir zone (SZ). Nilai kekerasan paling rendah diperoleh pada area stir zone spesimen hasil las dengan kedalaman $1,6 \mathrm{~mm}$ yakni sebesar 55.58 BHN. Hasil penelitian ini secara umum menunjukkan adanya peningkatan kualitas hasil pengelasan gesek puntir Mg AZ31 dua muka bila dibandingkan dengan satu muka las.

\section{Ucapan Terima Kasih}

Penulis mengucapkan terima kasih atas financial support pelitian ini melalui Hibah DIPA FT Skim Kerja sama Internasional Matching Grant 2021.

\section{Daftar Pustaka}

[1] Buldum, B.B., Sik, A., Ozkul, I. 2011. "Investigation of Magnesium Alloys". Turki. International Journal of Electronics; Mechanical and Mechatronics Engineering Vol.2, No.3, Hal. 261-268.

[2] Ibrahim, F. 2018. Pengaruh Bentuk Pin indentor Las Gessek Puntir (Friction Stir Welding) Terhadap Kualitas Hasil Lasan Magnesium AZ31. Skripsi. Universitas Lampung. Lampung.

[3] Marinov, V. 2010. "Manufacturing Technology". Dubuque. Kendall Hunt Publishing Company.

[4] Prasetyana, D. 2016. "Pengaruh Kedalaman Pin (Depth Plunge) Terhadap Kekuatan Sambungan Las Pada Pengelasan Adukan Gesek Sisi Ganda (Double Sided Friction Stir Welding) Alumunium Seri 5083". Skripsi. Teknik Mesin Universitas Muhammadiyah Surakarta. Solo.

[5] Santos, T., Vilaca, P., Quintino, L. 2007. "Developments in NDT for Detecting Imperfections in Friction Stir Welding in Alumunium Alloys". Lisbon.

[6] Santoso, B. 2014. Pengaruh variasi waktu gesekan awal solder terhadap kekuatan tarik, kekerasan dan struktur makro Alumunium 5083 pada pengelasan friction stir welding. Tugas Akhir. Universitas Lampung.

[7] Sudrajat, A. F. P. 2012. "Analisis Sifat Mekanik Hasil Pengelasan AA 1100 Dengan Metode Friction Stir Welding (FSW)". Fakultas Teknik Universitas Jember, Jember.

[8] Sukmana, I., Sustiono, A. 2016. "Pengaruh Kecepatan Putar Indentor Las Gesek Puntir (Friciton Stir Welding) terhadap kualitas pengelasan Alumunium 1100-H18". Jurnal Mechanical. Vol. 7, No. 1, Hal 15-19.



Irza Sukmana holds his Ph.D. degree in Chemical and Biotechnologycal Engineering from Universite de Sherbrooke, QC, Canada 2010. $\mathrm{He}$ is an associate Professor at the Dept. of Mechanical Engineering, Faculty of Engineering, Universitas Lampung, Indonesia. His current interest is in materials, mechanical engineering and biomedical science and tissue engineering.

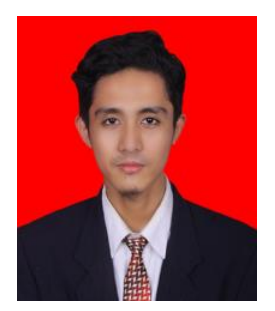

Hafiz F. Gustin menyelesaikan studi program sarjana di Jurusan Teknik Mesin, Fakultas Teknik, Universitas Lampung pada tahun 2020. Penelitan skripsinya berkaitan dengan teknologi las untuk Magnesium AZ31. Saat ini ia sedang mencari peluang dan tantangan untuk dapat berkarir di dunia industri.



Tarkono menyelesaikan studi program sarjana di Jurusan Teknik Pemesinan Kapal, Universitas Patimura (1996) dan PS Magister Teknik Produksi dan Material Kelautan di Institut Teknologi Sepuluh November (2006). Bidang kajian penelitiannya saat ini adalah berkaitan material maju dan teknik produksi dan manufaktur. 